Subject Category: Reactors-Research and Power

\title{
THE REACTION BETWEEN HYDROGEN AND OXYGEN
}

BY CATALYSIS AND THE THERMAL REACTION

Photostat Price $\$ \quad 4.80$
Microfilm Price $\$ 2.20$
Available from the
Office of Technical Services
Department of Commerce
Washington 25, D. C.

\author{
D. W. Kuhn \\ A. D. Ryon \\ A. A. Palko \\ January 15,1952 \\ G. H. Clewett, Director
}

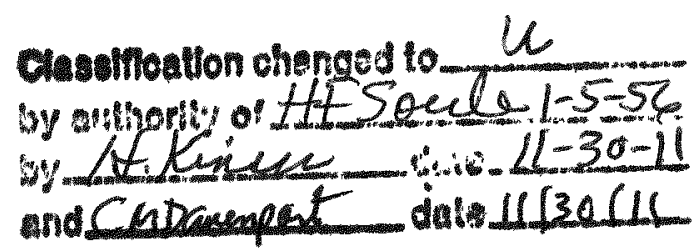

\section{MATERIALS CHEMISTRY DIVISION}

OAK RIDGE NATIONAL LABORATORY

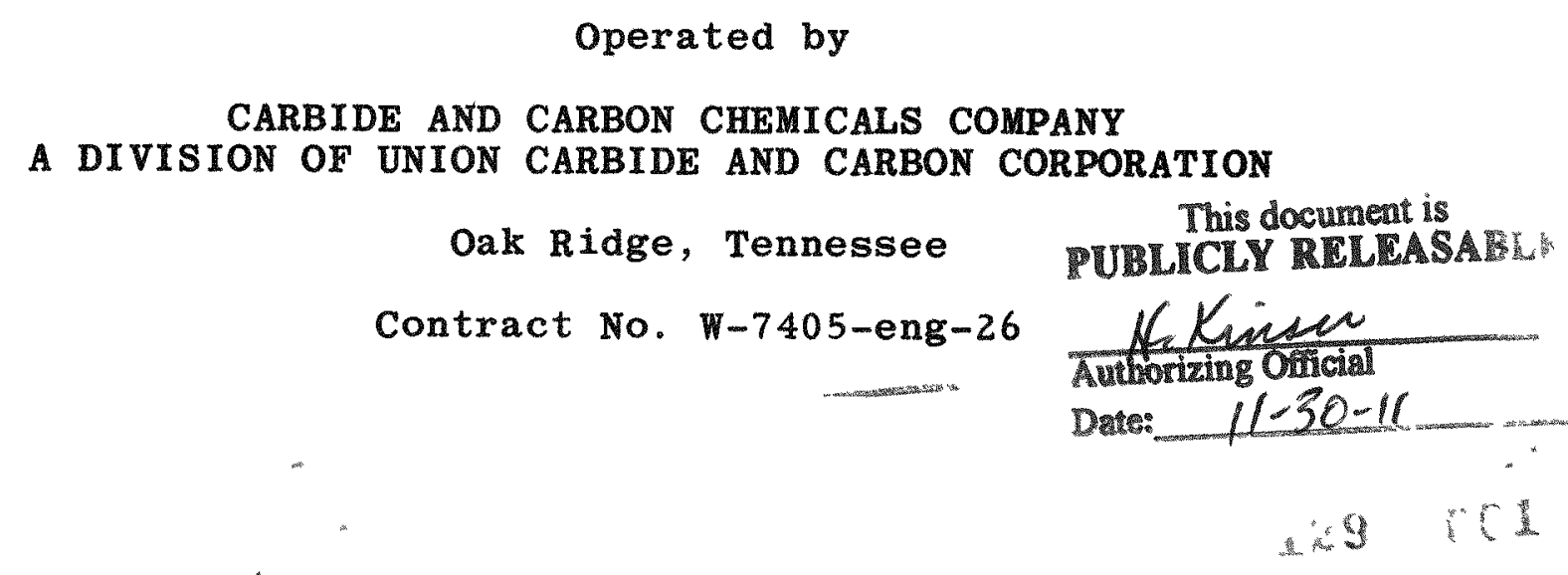




\section{DISCLAIMER}

This report was prepared as an account of work sponsored by an agency of the United States Government. Neither the United States Government nor any agency Thereof, nor any of their employees, makes any warranty, express or implied, or assumes any legal liability or responsibility for the accuracy, completeness, or usefulness of any information, apparatus, product, or process disclosed, or represents that its use would not infringe privately owned rights. Reference herein to any specific commercial product, process, or service by trade name, trademark, manufacturer, or otherwise does not necessarily constitute or imply its endorsement, recommendation, or favoring by the United States Government or any agency thereof. The views and opinions of authors expressed herein do not necessarily state or reflect those of the United States Government or any agency thereof. 


\section{DISCLAIMER}

Portions of this document may be illegible in electronic image products. Images are produced from the best available original document. 
Distribution, Series A:

Index No. ORNL-1209

$1-39$.

$40-42$.

43-52.

53.

54-61.

62.

63-65.

66.

67.

68.

69-73.

74.

$75-78$.

79.

80-83.

84.

$85-88$.

89-91.

92.

93-94.

95.

$96-97$.

98-99.

100 。

101.

102-103.

104-107.

$108-110$.

$111-125$.
Carbide and Carbon Chemicals Company ( $\mathrm{Y}-12$ Area)

Aircraft Nuclear Propulsion Project

Argonne National Laboratory

Armed Forces Special Weapons Project (Sandia)

Atomic Energy Commission, Washington

Battelle Memorial Institute

Brookhaven National Laboratory

Bureau of Ships

Chicago Patent Group

Chief of Naval Research

duPont Company

H. K. Ferguson Company

General Electric Company, Richland

Hanford Operations Office

Idaho Operations Office

Iowa State College

Knolls Atomic Power Laboratory

Los Alamos

Massachusetts Institute of Technology (Kaufmann)

Mound Laboratory

National Advisory Committee for Aeronautics

New York Operations Office

North American Aviation, Inc.

Patent Branch, Washington

Savannah River Operations Office

University of California Radiation Laboratory

Westinghouse Electric Corporation

Wright Air Development Center

Technical Information Service, Oak Ridge

Carbide and Carbon Chemicals Company internal distribution as follows:

1. C. E. Center

2. C. E. Larson

3. W. B. Humes

4. W. D. Lavers

5. A. M. Weinberg

6. E. H. Taylor

7. E. J. Murphy

8. E. D. Shipley

9. J. A. Swartout

10. F. O. Steahly

11. C. E. Winters
12. C. H. Secoy

13. C. G. Graham

14. R. N. Lyon

15. S. E. Beall

16. J. P. Gill

17. E. G. Bohlmann

18. R. B. Briggs

19. C. L. Segaser

20. J. R. McWharter

21. J. A. Ransohoff

22. H. F. McDuffy
23.

24.

25.

26.

27.

28.

29.

30.

31.

32-35. $X-10$ Central Files

36-39. $Y-12$ Central Files

Issuing Office

Technical Information Department, Y-12 Area

Date Issued: FEB 81952 


\section{ABSTRACT}

The reaction between hydrogen and oxygen with the aid of various catalysts (especially platinum on alumina) has been studied, and the operating variables such as flow rates, space velocity, temperature, and gas composition have been examined rather extensively. It has been found that hydrogen and oxygen in stoichiometric proportions and mixed with either steam or helium may be made to react to the extent of $99.5 \%$ or greater at space velocities up to $30,000 \mathrm{hr}^{-1}$, or even higher, at temperatures from $100^{\circ}$ to $900^{\circ} \mathrm{C}$, and with mixtures ranging from less than $1 \%$ hydrogen to mixtures containing $12 \%$ hydrogen and $6 \%$ oxygen. Richer mixtures, including undiluted electrolytic gas $\left(\mathrm{H}_{2}+1 / 2 \mathrm{O}_{2}\right)$ have been used with catalysts less active than platinum ( $e . g$. copper, silver, nickel and $\mathrm{V}_{2} \mathrm{O}_{5}$ ) but here the gas mixture is explosive and care must be taken to prevent explosions.

The thermal reaction between hydrogen and oxygen diluted with stean has also been investigated at temperatures between $500^{\circ}$ and $800^{\circ} \mathrm{C}$. 
THE REACTION BETWEEN HYDROGEN AND OXYGEN

BY CATALYSIS AND THE THERMAL REACTION

\section{INTRODUCTION}

Fission of uranium in aqueous solution results in some decomposition of water into hydrogen and oxygen, due principally to the high energy fission recoils. One of the problems associated with aqueous homogeneous reactors is then the disposal of this hydrogen and oxygen. The most satisfactory arrangement would be to retain the gaseous products within the reactor and effect a chemical recombination of hydrogen and oxygen to form water. With this general goal in view, the present study was undertaken to develop suitable means for achieving this hydrogenoxygen recombination.

Three general methods have been considered:

1. Burning the hydrogen.

2. Effecting the hydrogen-oxygen reaction by means of a catalyst.

3. Making use of the thermal reaction between hydrogen and oxygen.

A11 of the work on the burning of hydrogen has been carried out by another group under the direction of H. M. McLeod, and results of that work have been reported elsewhere. 1 The material presented in this report is that included under points 2 and 3 above. It may be well to describe what is meant by the thermal reaction, and to point out that the thermal reaction and burning of hydrogen are quite different. Burning implies a flame and a rapid rate of reaction; the thermal reaction is very much slower than burning, is "flameless", and in fact does not require a combustible mixture in order to proceed. The thermal reaction proceeds by a free radical mechanism and has been observed at temperatures of less than $500^{\circ} \mathrm{C}$. It may also be observed at higher temperatures, but above the ignition temperature (about $550^{\circ} \mathrm{C}$ ) explosion will be encountered unless the gases are diluted below the explosion limit. 


\section{CATALYTIC RECOMBINATION OF HYDROGEN AND OXYGEN}

General Considerations

In the organization and presentation of the material included in this report, certain conventions and definitions have been adopted and will be stated here. The term "percent conversion" has been used to designate that percentage of the hydrogen and oxygen which is converted to water during passage through a catalyst. Normally the gas supplied to a catalyst contained exactly two moles of hydrogen per mole of oxygen, so that the percent conversion could be based on either hydrogen or oxygen or upon the stoichiometric mixture. In those cases where one constituent was supplied in excess, the percent conversion was of course calculated on the basis of the deficient constituent. The term space velocity has been defined as follows: spage velocity is the number of volumes of gas mixture, measured at $0 \mathrm{C}$ and 1 atm., passing per hour through a unit volume of catalyst bed. For example, if the flow rate of the gas is 3000 liters per hour (when measured at $0^{\circ} \mathrm{C}$ and 1 atm) and the volume occupied by the catalyst is 0.5 liters, the space velocity is $30001 . / \mathrm{hr}=6000 \mathrm{hr}^{-1}$.

The volume of the catalyst bed is taken to include the void spaces between individual particles as well as actual catalyst volume. For example, if the catalyst is packed in a pipe of inside diameter d and fills a section of length 1 , the catalyst volume is $\pi \frac{\mathrm{d}^{2} 1}{4}$. It will be noted that space velocity is calculated on the basis of all of the gas supplied to the catalyst, so that for mixtures of hydrogen and oxygen with steam or other diluent, it is necessary to state the percentage composition of the gas mixture as well as space velocity in order to determine the standard flow rate of hydrogen, for example. It is also obvious that the actual volumetric flow rate of gas through a catalyst will depend on the temperature and pressure of the gas in the catalyst zone, and hence will differ from the flow rate expressed at the standard conditions of $0^{\circ} \mathrm{C}$ and 1 atm.

Space velocity has the dimension reciprocal time. The space velocity is seen to be inversely proportional to the residence time or contact time of the gas on the catalyst. If two experiments with a given shape of catalyst but not necessarily the same weight of catalyst are run at the same space velocity and at the same operating temperature and pressure, the contact time will be the same. 
Experimental Methods

The apparatus required for a typical experiment in this study was as follows: (1) a source of hydrogen and oxygen, usually an electrolytic cell containing 15\% NaOH, stainless steel cathode and anode with which hydrogen and oxygen were produced by electrolysis; (2) a source of superheated steam which was mixed with the "electrolytic gas" $\left(\mathrm{H}_{2}+1 / 2 \mathrm{O}_{2}\right)$ to dilute the gas to a non-explosive mixture, i.e., less than $20 \%$ electrolytic gas; (3) this non-inflammable mixture was maintained through several feet of small diameter pipe or tubing which thereby served as a flame arrestor. A flame propagating from the catalyst back toward the electrolytic cell would be extinguished in this section; (4) a condenser to remove this "flame arrestor steam"; (5) a metered supply of diluent to be mixed with electrolytic gas. Steam was commonly used as the diluent, and was superheated to avoid wetting the catalyst; (6) the catalytic reactor, usually a straight section of stainless steel pipe mounted vertically and packed with a layer of catalyst, the catalyst being supported on a wire screen, with the gas inlet at the top; (7) means for metering off-gas. This was usually done by condensing the steam and collecting permanent gases by displacement of water in inverted volumetric flasks. The rate of flow of electrolytic gas to the catalyst was conveniently determined by the ammeter reading showing current passed through the electrolysis cell. This ammeter reading was calibrated by actual measurement of gas volume produced, again by collection of the gas over water in a volumetric flask during a timed interval. The steam flow rate was determined by collecting the condensate over a timed interval and calculating the steam flow rate from known density data. For uniformity in the calculation of standard flow rates and space velocities, hypothetical steam at $0^{\circ} \mathrm{C}$ and $1 \mathrm{~atm}$. was assumed by applying the ideal gas law to actual steam at $100^{\circ} \mathrm{C}$ and $1 \mathrm{~atm}$.

When using steam as a diluent, it was found to be important to prevent condensation in the gas lines and on the catalyst itself. The section of tubing constituting the flashback arrestor would be of no value if steam were allowed to condense to the point where the composition of the mixture was in the explosive range. Also, a surface catalyst can not work if covered by a film of water. For this reason one or more heaters were used in the gas supply lines to maintain the steam mixtures at temperatures above the dew point.

Temperature measurement in the catalyst bed was a rather important part of this work. In most cases a thermocouple well 
extended along the longitudinal axis of the catalytic reactor so that a thermocouple could be moved through the bed from top to bottom during any test. In the large $4^{\text {" pipe reactor, two }}$ additional thermocouples were soldered to the inside wall of the reactor in order to show the radial temperature gradient.

In order to produce electrolytic gas on a large scale (14 Iiters per minute) a set of twelve cells were constructed, each of which passed 100 amperes of direct current. The voltage drop per cell was about 2.8 volts at 100 amperes. In this case black iron pipe was substituted for stainless steel. A cell consisted of two concentric pipes, electrically insulated from each other by means of rubber spacers. A $33^{\text {" }}$ length of $1-1 / 4^{\prime \prime}$ pipe was inserted into a $29^{\prime \prime}$ length of $3^{\prime \prime}$ pipe, which was capped at the bottom and fitted with a flange at the top. The annulus between pipes at the top was closed by a 1-hole rubber stopper cut to it snugly around the $3 / 4^{\prime \prime}$ pipe and pressed in place by a pair of flanges. A $15 \%$ solution of NaOH served as the electrolyte. For flow rates greater than 14 liters of electrolytic gas per minute, compressed gas cylinders of hydrogen and oxygen were used.

Platinum on Aluminum Oxide

Much of the work with platinum catalysts has been done with $0.3 \% \mathrm{Pt}-\mathrm{On}-\mathrm{Al}_{2} \mathrm{O}_{3}$. This product, available from either Baker and Company, Inc., Newark, New Jersey, or Jo Bishop and Company platinum Works, Malvern, $\mathrm{Pa}$, was supplied in the form of cylindrical $\mathrm{Al}_{2} \mathrm{O}_{3}$ pellets, $1 / 8^{\prime \prime}$ diameter $\mathrm{x} 1 / 8^{\prime \prime}$ long, with a surface coating of platinum. The catalyst has been shown to be very effective in converting hydrogen-oxygen mixtures to water over a broad range of conditions of temperature, flow rate, space velocity, and composition of gas mixtures.

Results of typical experiments have been selected and are presented in Table 1 .

From the data in Table 1 , it is seen that essentially complete reaction was obtained for all space velocities employed ( 5000 to $200,000 \mathrm{hr}^{-1}$ ) and at both low and high temperatures. The catalyst was not damaged or impaired in any way by exposure to reactant gases and steam at $900^{\circ} \mathrm{C}$. The composition of the gas feed material may vary from very dilute mixtures up to an upper limit which is determined by the explosion limit. For mixtures of electrolytic gas and steam, this 1 imit is about $22 \%$ electrolytic gas. 2 Mixtures richer than this would produce explosions if passed over a platinum catalyst. The above limit is applicable only to mixtures containing hydrogen and oxygen in the stoichiometric ratio. If excess oxygen is present, the explosion limit will be lowered. 


\section{Table 18}

The Reaction Between Hydrogen and Oxygen Using $0.3 \%$ Pt-on- $\mathrm{Al}_{2} \mathrm{O}_{3}$ Catalyst

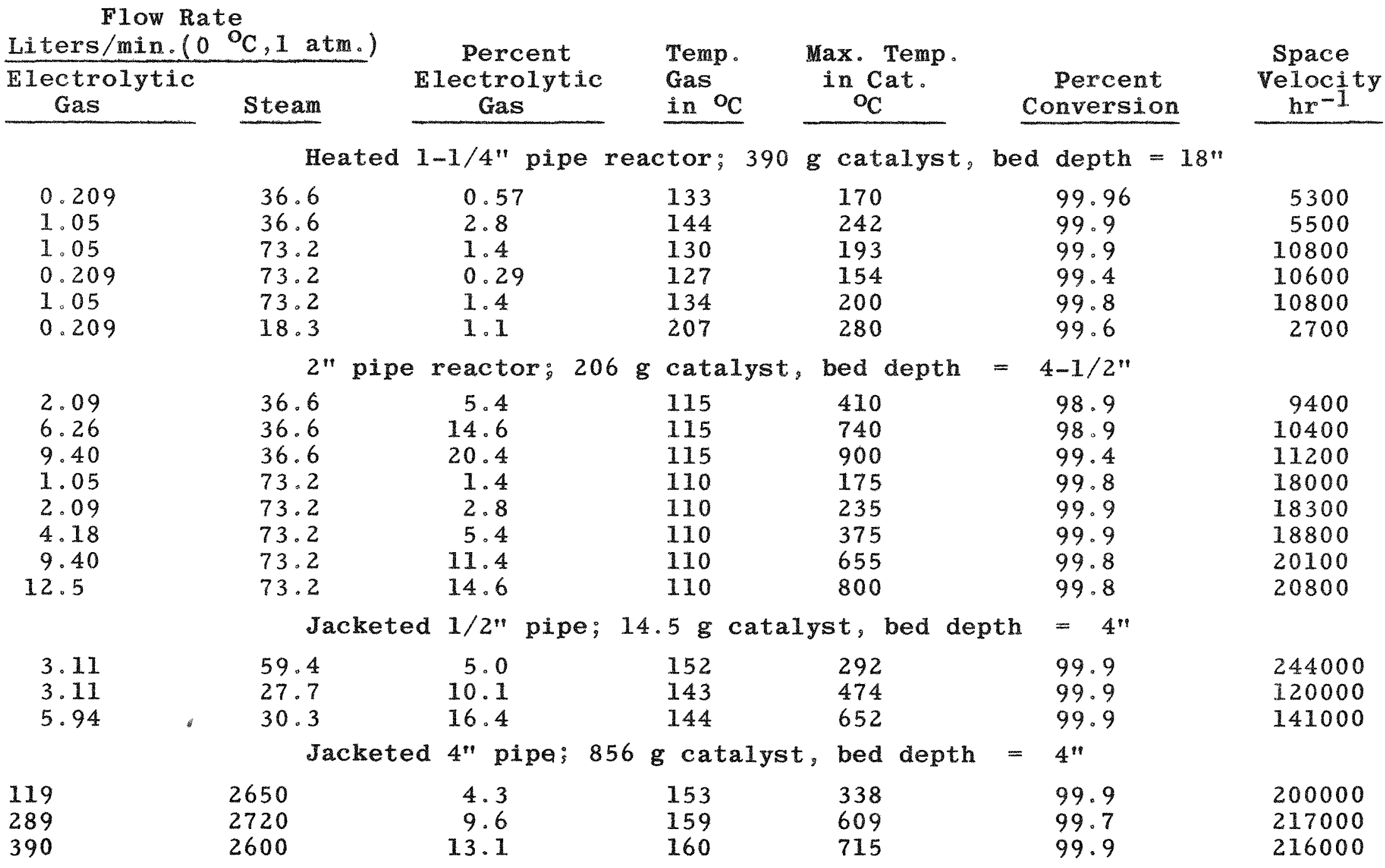


Two-Stage Catalytic Recombiner

If large quantities of hydrogen and oxygen are to be recombined, it would be more economical with regard to size of equipment and quantity of catalyst required if one were to employ a two-stage catalytic unit. Then the first unit would be required to give not greater than 90-95\% conversion, which would allow considerably less catalyst to be used. Following this first stage would be a cooler which would remove about $90 \%$ of the steam from the mixture leaving the first reactor. This reduction in gas volume would allow the second catalytic unit to be even smaller than the first, and the over-all conversion could easily be made to exceed $99.9 \%$. The quantity of catalyst required to yield the same end result using a single catalytic unit would be more than twice the total amount of catalyst used in a two-stage unit.

Removal of Heat from the Catalyst

A number of experiments have been completed which furnish information concerning the control of temperature in a catalytic reactor and the removal of heat of reaction. These tests show that the heat of the hydrogen-oxygen recombination can be removed from a catalytic reactor without difficulty. In these experiments the reactor was jacketed, and cooling water was passed through the jacket to cool the reactor wall. In one series a $4^{\prime \prime}$ pipe containing catalyst was jacketed by a $5^{\prime \prime}$ pipe; in another, a $1 / 2$ " pipe was jacketed by a $1-1 / 2^{\prime \prime}$ pipe; and in the third series, the reactor was a tube and shell heat exchanger containing seventeen $1 / 4^{\prime \prime}$ pipes, with catalyst packed inside the 1/4" pipes and coolant circulated through the shell. The results of these tests appear in Table 2 .

Examination of these results shows that the temperature of the gases leaving the catalytic reactor is readily controlled by using small diameter tubes with relatively large heat transfer surface, or alternatively by limiting the composition of the gas feed to dilute mixtures. In the last set of data obtained with the 1/2" pipe reactor, as given in Table 2 , the feed mixture contained $16.4 \%$ electrolytic gas and the maximum gas temperature recorded was $652^{\circ} \mathrm{C}$. However, this gas was cooled to $210^{\circ} \mathrm{C}$ before leaving the reactor. The reactor was $28^{\prime \prime}$ in length, but was unpacked except for the $4^{\text {" }}$ bed of catalyst.

The diameter of the catalytic reactor need not necessarily be small, as shown by the first set of results in Table 2 . This reactor was made of 4" pipe, jacketed by a $5 "$ pipe, the length of the jacketed section being $14^{*}$. A bed of catalyst pellets $4^{\text {" }}$ deep was supported within the jacketed zone; the rest of the space was not packed. Such a reactor may be operated with no

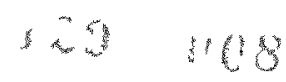




\section{Table $2 \quad 10$}

Heat Transfer in Recombination of Hydrogen and Oxygen Using

\section{Platinum on Alumina Catalyst}

\begin{tabular}{|c|c|c|c|c|c|c|c|}
\hline & & & & $\begin{array}{l}\text { Heat of } \\
\text { Reaction } \\
\text { Troasferred }\end{array}$ & $\begin{array}{l}\text { Total } \\
\text { Gas Flow }\end{array}$ & & $\begin{array}{l}\text { Pressure } \\
\text { Drop }\end{array}$ \\
\hline $\begin{array}{l}\text { eactor Wall } \\
\text { Cat. Side }\end{array}$ & Out & In & $\begin{array}{l}\text { Low Rate } \\
\text { grams/min. }\end{array}$ & to Coolant & $\begin{array}{l}1 . / \min . \\
\left(0^{\circ} \mathrm{C}, 1 \text { atm。) }\right.\end{array}$ & 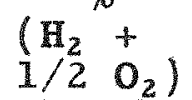 & $\begin{array}{l}\text { Cat. } \\
\text { psi. }\end{array}$ \\
\hline
\end{tabular}

$4^{\prime \prime}$ pipe reactor; bed depth $=4^{\prime \prime}$

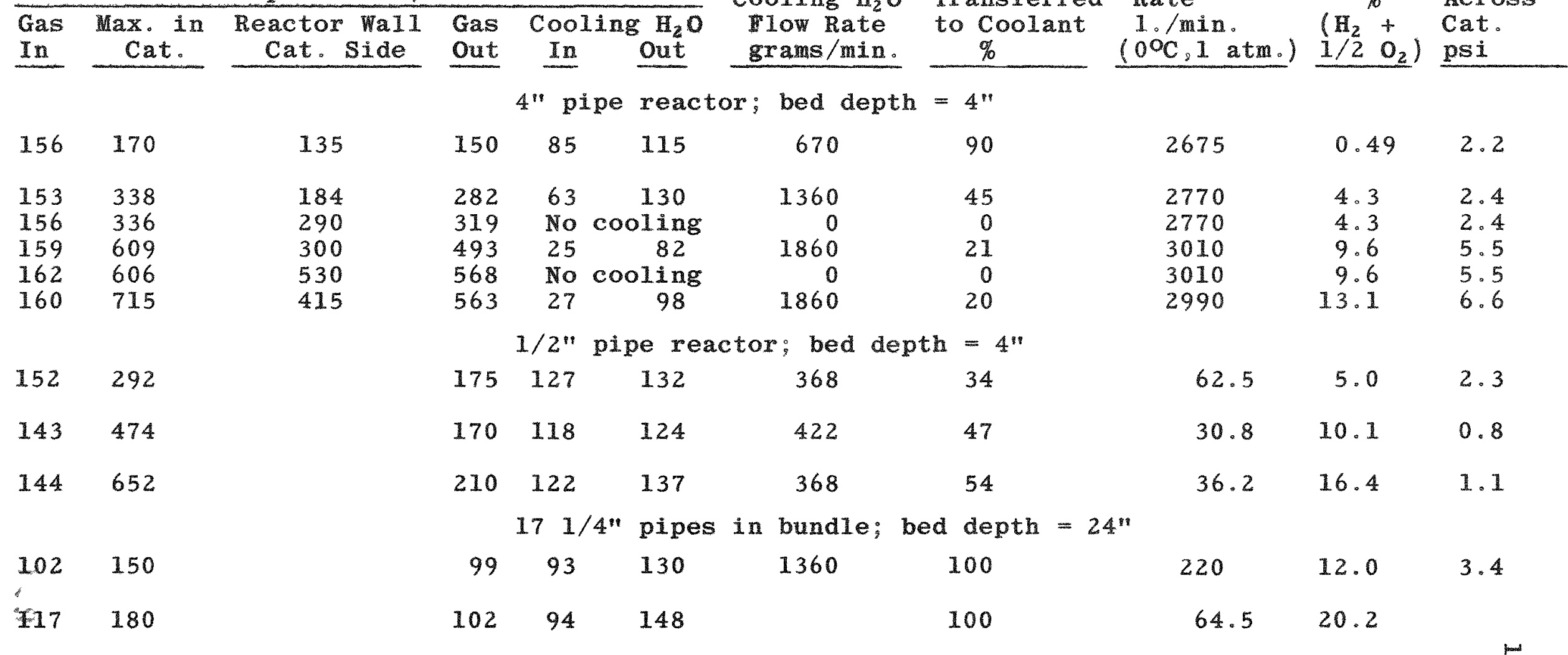


cooling, allowing the hot product steam to pass out into a conventional heat exchanger. Limitations on the maximum allowable operating temperature of reactor walls and of $f-g a s$ piping will requixe that the gas be diluted to the necessary degree. Data on 1 ine 5 of Table 2 show that an adiabatic reactor can convert $9.6 \%$ electrolytic gas $-90.4 \%$ steam, with all of the heat of reaction being removed in the exit steam at temperatures not exceeding $600^{\circ} \mathrm{C}$. Calculation shows that the observed temperature rise of 406 degrees $(568-162)$ is sufficient to account for all of the heat of reaction being removed in the product steam at the flow rates employed. If on the other hand it is desired to cool the reactor walls, an appreciable fraction of the heat of reaction can be extracted by the cooling water, as indicated in column 7 of the table. Here even richer gas mixtures may be handled.

It is interesting to note those cases where the same gas mixture was run in the $4^{*}$ pipe with cooling and without cooling. The temperature at the center of the catalyst (i.e., $2^{\prime \prime}$ from the walls) is independent of the wall temperature, and depends only on the composition of the gas feed. Also, cooling water lowered the inside wall temperature from $530^{\circ}$ to $300^{\circ} \mathrm{C}$ in one pair of tests.

Catalyst poisons

An important practical consideration in the application of a catalyst to a specific use is the question of how long the catalyst will remain active, or whether there are poisons which may reduce the activity of the catalyst. The effectiveness of a catalyst may be rapidly and seriously reduced by substances classed as "poisons". Such compounds as $\mathrm{H}_{2} \mathbf{S}, \mathrm{SO}_{2}$, and $\mathrm{CO}$, even if present only in small concentrations, are known to poison platinum catalysts. In the operation of a catalytic unit in the ORNL Homogeneous Reactor, one should not expect to encounter $\mathrm{H}_{2} \mathrm{~S}, \mathrm{SO}_{2}$, or $\mathrm{CO}$. Those gases which will be present in the reactor include bromine, iodine, krypton and xenon. It is thought that the inert gases krypton and xenon will have no effect on the catalyst. This has been found to be true using helium. In the case of the halogen gases, iodine will be present in much larger proportion than bromine, and in any case the behavior of one should be similar to the other. For this reason, our investigation of possible poisons was limited to the effect of iodine.

These experiments were carried out by mixing iodine vapor with hydrogen, oxygen, and steam, and passing this mixture through a heated pyrex tube containing 30 grams of $0.3 \%$ pt-on$\mathrm{Al}_{2} \mathrm{O}_{3}$ catalyst. The apparatus was made of glass in order to prevent loss of iodine by corrosion of metal surfaces. The 
results of this work are presented in Table 3 .

These experiments on poisoning with iodine showed that relatively large amounts of iodine could be passed through the platinum-on-alumina catalyst with only a small loss in efficiency provided that the temperature of the catalyst was about $500^{\circ} \mathrm{C}$ or higher. The effect was decidedly more noticeable at lower temperatures. poisoning the catalyst with iodine at $200^{\circ} \mathrm{C}$ reduced the percent conversion to only $5 \%$. However, simply heating the poisoned catalyst to $503^{\circ} \mathrm{C}$ volatilized iodine and restored the catalyst efficiency to $97.9 \%$. It is also seen that the percent conversion fell off soon after initial exposure to iodine, and at a given temperature reached some constant value which was not altered by further prolonged exposure to iodine. Lowering the temperature dropped this conversion to a lower value, where it again approached a constant value at constant temperature.

In practice, the iodine poisoning problem can be dealt with in either of two ways: (1) the catalyst bed can be maintained at temperatures above $400^{\circ} \mathrm{C},(2)$ iodine can be removed from the gases ahead of the catalyst by means of a suitable scrubber or trap.

Platinum-on-Charcoal

Chronologically, the work with the charcoal base catalyst preceded that with the alumina base catalyst. The same experimental procedure was followed for both, and the performance of one catalyst was found to be comparable to that of the other. There exists, however, one outstanding advantage of alumina over charcoal. It was found that the charcoal catalyst, when operated in the presence of hydrogen, oxygen, and steam, was oxidized with the formation of $\mathrm{CO}_{2}$ at temperatures above $400^{\circ} \mathrm{C}$. The alumina catalyst, on the other hand, was satisfactory over the entire temperature range of interest, even at temperatures as high as $900^{\circ} \mathrm{C}$. For this reason, the charcoal catalyst has been replaced by the alumina catalyst.

The charcoal catalyst which was used had been developed for another purpose on the Manhattan project and was designated as product 43. It contained 1.1\% platinum on irregular pieces of charcoal of approximately 8-10 mesh in size. It proved to be an efficient catalyst for the hydrogen-oxygen reaction, as can be seen from the results given in Table 4.

Poisoning of platinum-on-Charcoal Catalyst with lodine

Experiments identical with those previously described for the $\mathrm{Pt}-\mathrm{on}-\mathrm{Al}_{2} \mathrm{O}_{3}$ catalyst were also carried out with iodine on 
Table 3

Poisoning of $\mathrm{Pt}$-on- $\mathrm{Al}_{2} \mathrm{O}_{3}$ by Iodine

5 -inch bed of catalyst in $3 / 4 "$ pyrex tube ( $30 \mathrm{~g}$ of catalyst)

$$
\text { Space velocity }=13,000 \mathrm{hr}^{-1}
$$

\begin{tabular}{|c|c|c|c|c|c|}
\hline \multirow[b]{2}{*}{$\begin{array}{l}\text { Max. Cat. } \\
\text { Temp. }{ }^{\circ} \mathrm{C} \\
\end{array}$} & \multicolumn{3}{|c|}{ Flow Rates } & \multirow{2}{*}{$\begin{array}{l}\text { Duration of } \\
\text { Exposure of } \\
\text { Cat.to Iodine } \\
\text { (hrs) } \\
\end{array}$} & \multirow[b]{2}{*}{$\begin{array}{l}\text { \% Con- } \\
\text { version }\end{array}$} \\
\hline & $\begin{array}{l}\mathrm{H}_{2}+1 / 2 \mathrm{O}_{2} \\
\text { liters/min. }\end{array}$ & $\begin{array}{c}\text { Steam } \\
\text { liters/min. }\end{array}$ & $\begin{array}{l}\text { Iodine } \\
\mathrm{mg} / \mathrm{hr}\end{array}$ & & \\
\hline 510 & 0.63 & 9.4 & 0 & 0 & 99.6 \\
\hline 510 & 0.63 & 9.4 & 68 & $1-1 / 4$ & 97.1 \\
\hline 510 & 0.63 & 9.4 & 68 & $2-2 / 3$ & 96.8 \\
\hline 510 & 0.63 & 9.4 & 68 & 18 & 96.2 \\
\hline 520 & 0.63 & 9.4 & 68 & 26 & 96.3 \\
\hline 200 & 0.31 & 10.0 & 34 & 29 & 9.1 \\
\hline 200 & 0.31 & 10.0 & 34 & 46 & 5.2 \\
\hline 400 & 0.31 & 9.7 & 0 & 46 & 96.2 \\
\hline 503 & 0.78 & 9.7 & 0 & 46 & 97.9 \\
\hline
\end{tabular}


Table 4

The Reaction Between Hydrogen and Pxygen

Using 1.1\% Platinum-on-Charcoal Catalyst

3/4" pipe reactor; $18 \mathrm{~g}$ of catalyst; bed depth $=4^{n}$

Flow Rate

liters/min.

\begin{tabular}{|c|c|c|c|c|c|c|}
\hline$\frac{\left(0^{\circ} \mathrm{C}\right.}{\text { Gas }}$ & Steam & $\begin{array}{c}\% \\
\text { Elect. } \\
\text { Gas }\end{array}$ & $\begin{array}{l}\text { Temp. } \\
\text { Gas in } \\
{ }^{\circ} \mathrm{C}\end{array}$ & $\begin{array}{l}\text { Max. Temp } \\
\text { in Cat. } \\
{ }_{O_{C}}\end{array}$ & Conversion & $\begin{array}{c}\text { Space } \\
\text { Velocity } \\
\text { hr }-1\end{array}$ \\
\hline $\begin{array}{l}0.52 \\
0.52 \\
0.52 \\
0.52\end{array}$ & $\begin{array}{l}64 \\
64 \\
64 \\
64\end{array}$ & $\begin{array}{l}0.81 \\
0.81 \\
0.81 \\
0.81\end{array}$ & $\begin{array}{l}140 \\
160 \\
185 \\
215\end{array}$ & $\begin{array}{l}170 \\
195 \\
215 \\
240\end{array}$ & $\begin{array}{l}86.0 \\
94.8 \\
97.9 \\
98.9\end{array}$ & $\begin{array}{l}120,000 \\
120,000 \\
120,000 \\
120,000\end{array}$ \\
\hline $\begin{array}{l}0.26 \\
0.52 \\
1.04 \\
0.26 \\
0.52 \\
1.04\end{array}$ & $\begin{array}{l}64 \\
64 \\
64 \\
64 \\
64 \\
64\end{array}$ & $\begin{array}{l}0.40 \\
0.81 \\
1.6 \\
0.40 \\
0.81 \\
1.6\end{array}$ & $\begin{array}{l}150 \\
150 \\
150 \\
185 \\
185 \\
185\end{array}$ & $\begin{array}{l}175 \\
190 \\
225 \\
205 \\
220 \\
250\end{array}$ & $\begin{array}{l}96.7 \\
97.6 \\
99.0 \\
98.2 \\
98.8 \\
99.2\end{array}$ & $\begin{array}{l}120,000 \\
120,000 \\
120,000 \\
120,000 \\
120,000 \\
120,000\end{array}$ \\
\hline $\begin{array}{l}0.26 \\
0.52 \\
0.78 \\
1.04 \\
0.26 \\
0.52 \\
0.78 \\
1.04\end{array}$ & $\begin{array}{l}29 \\
29 \\
29 \\
29 \\
15 \\
15 \\
15 \\
15\end{array}$ & $\begin{array}{l}0.89 \\
1.8 \\
2.6 \\
3.5 \\
1.7 \\
3.4 \\
4.9 \\
6.5\end{array}$ & $\begin{array}{l}125 \\
125 \\
125 \\
125 \\
125 \\
125 \\
125 \\
125\end{array}$ & $\begin{array}{l}145 \\
180 \\
215 \\
250 \\
182 \\
237 \\
302 \\
360\end{array}$ & $\begin{array}{c}90.0 \\
96.2 \\
98.4 \\
99.2 \\
99.98 \\
99.95 \\
99.83 \\
-\end{array}$ & $\begin{array}{l}55,000 \\
55,000 \\
55,000 \\
55,000 \\
28,000 \\
28,000 \\
28,000 \\
28,000\end{array}$ \\
\hline
\end{tabular}


the platinum-on-charcoal catalyst. The only point of difference was again the temperature limitation of the charcoal catalyst, which can not be used at $500^{\circ} \mathrm{C}$ without oxidation of the charcoal. Results are given in Table 5 .

\section{Table 5 \\ Poisoning of platinum-on-Charcoal by Iodine}

$35 \mathrm{~g}$ of $1 \%$ platinum-on-charcoal catalyst; bed depth $=8-3 / 4^{\circ}$

Space velocity $=13,000 \mathrm{hr}^{-1}$

Flow rates: Steam, 10 liters/min.

Electrolytic gas, 0.25 liters/min.

Maximum

Catalyst

Temp. $\left({ }^{\circ} \mathrm{C}\right)$

365

365

365

365

322

322

195

195

383

320

230

156
Iodine Flow

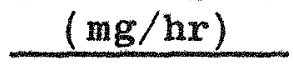

34

34

34

34

34

34

34

34

0

0

0
Duration of Exposure of Catalyst to Iodine (hours)

0
$1-1 /$
$9-1 /$
38
54
62
79
84
84
84
84
84

Percent Conversion

99.9

99.6

99.0

99.0

96.0

96.0

9.0

9.0

96.0

80.0

32.0

20.0

It is evident that iodine poisons the catalyst at low temperatures $\left(200^{\circ} \mathrm{C}\right)$, but the effect gradually lessens as the temperature is increased, until at temperatures of about $375^{\circ} \mathrm{C}$ the poisoning is only slight.

Other Catalysts - Pd, Cu, Ag, Ni, $\mathrm{V}_{2} \mathrm{O}_{5}$

Comparison of platinum with palladium. The relative merits of platinum and palladium as catalysts for the hydrogen-oxygen reaction have been compared. A few simple tests have been conducted on each type of catalyst to compare:

1. Activity at room temperature when catalyst is dry

2. Activity at room temperature when catalyst is wet.

The catalysts, both purchased from Baker and Company, Inc., Newark, New Jersey, were each in the form of cylindrical $\mathrm{Al}_{2} \mathrm{O}_{3}$ 
pellets $1 / 8^{\prime \prime}$ diameter $x$ 1/8" long, with the noble metal coated on the surface of the pellets. Chemical analysis of these catalysts were as follows: $0.3 \% \mathrm{Pt}, 0.020 \% \mathrm{CI}$; and $0.3 \% \mathrm{Pd}$, $0.025 \% \mathrm{Cl}$. Thirty grams of catalyst were packed inside the inner tube of a pyrex condenser, forming a bed $6-1 / 2^{\text {" }}$ long $x$ 5/8" in diameter. A mixture of $180 \mathrm{cc} / \mathrm{min}$ of electrolytic gas $\left(2 \mathrm{H}_{2}+\mathrm{O}_{2}\right)$ and $2670 \mathrm{cc} / \mathrm{min}$. of helium was passed through the catalyst under various conditions, as indicated in the table which follows. Temperatures shown were taken at the hottest point within the catalyst, which was $1 / 4^{\prime \prime}$ from head of bed.

From these parallel experiments on the two types of catalyst, it is seen that both catalysts are active at room temperature when dry, and that the reaction begins immediately. In runs 3 and 7 , the catalyst was initially flooded with water, but no more water was added after starting gas mixture through the bed. Here no reaction occurred until portions of the catalyst became dry, after which the heat of reaction quickly dried a large portion of the bed. The wet platinum catalyst responded more rapidly than did the palladium. Reaction on the wet platinum catalyst became evident after 7 minutes had elapsed, while 17 minutes were required by the palladium for comparable reactivity. Finally, if by some means the catalyst is maintained wet, no reaction will occur for an indefinite period of time. This was shown not only by the absence of any temperature rise, but also by measurement of the volume of gas mixture entering and leaving the reactor. These measurements showed zero percent conversion in runs 4 and 8 , and $100 \%$ conversion in all other runs, once the reaction had begun.

Copper, Silver, and Nickel

Metallic copper, silver, and nickel each exhibit catalytic activity for the hydrogen-oxygen reaction, although the activity of platinum is several orders of magnitude greater than any of these. As a consequence of this lower activity, however, it has been possible to recombine electrolytic gas catalytically without the necessity for diluting the reactants. In order to accomplish this, the heat of reaction must be removed at a rate sufficient to maintain every part of the system below the ignition temperature of the gas mixture $\left(550^{\circ} \mathrm{C}\right)$. This has been accomplished by passing the undiluted electrolytic gas through metal tubing which is completely immersed in a fused $\mathrm{KNO}_{3}-\mathrm{NaNO}_{2}$ salt bath. Copper, silver, and nickel tubing have each been employed, and each has been found to exhibit catalytic activity which improves markedly with increasing temperature. All of the experiments except one were run using unpacked tubes. In this case, a 5-foot length of $1 / 2^{\prime \prime}$ copper tubing (0.41" I.D.) 


\section{Table 617}

\section{Comparison of Platinum with Palladium Catalyst}

\begin{tabular}{|c|c|c|c|c|c|c|c|c|}
\hline \multirow[b]{3}{*}{$\begin{array}{l}\text { Time after } \\
\text { starting } \\
\text { flow of gas } \\
\text { (min.) } \\
\end{array}$} & \multicolumn{4}{|c|}{ Platinum } & \multirow{2}{*}{\multicolumn{4}{|c|}{ Palladium }} \\
\hline & & & $\operatorname{Bun} 3$ & & & & & \\
\hline & $\begin{array}{c}\text { Run } 1 \\
\text { Dry cat. } \\
\text { No cooling } \\
\end{array}$ & $\begin{array}{l}\text { Dry cat. } \\
\text { Cooling } \\
\text { water run } \\
\text { thru jacket } \\
\text { of condenser } \\
\end{array}$ & $\begin{array}{l}\text { Cat. wet } \\
\text { at start. } \\
\text { Cat. } \\
\text { cooled } \\
\end{array}$ & $\begin{array}{l}\text { Water } \\
\text { dripping } \\
\text { on cat. } \\
\text { thru-out run } \\
\text { Cat. cooled } \\
\end{array}$ & $\begin{array}{l}\text { Run } 5 \\
\text { Same } \\
\text { as } 1 \\
\text { Run } 1 \\
\end{array}$ & $\begin{array}{l}\text { Run } 6 \\
\text { Same } \\
\text { as } \\
\text { Run 2 } \\
\end{array}$ & $\begin{array}{l}\text { Run } 7 \\
\text { Same } \\
\text { as } \\
\text { Run } 3 \\
\end{array}$ & $\begin{array}{l}\text { Run } 8 \\
\text { Same } \\
\text { as } \\
\text { Run } 4 \\
\end{array}$ \\
\hline 0 & $22^{\circ} \mathrm{C}$ & $21^{\circ} \mathrm{C}$ & $12^{\circ} \mathrm{C}$ & $19^{\circ} \mathrm{C}$ & $29^{\circ} \mathrm{C}$ & $180 \mathrm{C}$ & $18^{\circ} \mathrm{C}$ & $19^{\circ} \mathrm{C}$ \\
\hline 1 & 170 & 148 & 13 & 19 & 80 & & 16 & \\
\hline 2 & & & & & 204 & & & \\
\hline 3 & 306 & 217 & 15 & 19 & & 180 & & \\
\hline 4 & & & & & 312 & & 14 & \\
\hline 5 & & 214 & 28 & 19 & & $191^{\circ}$ & & \\
\hline 7 & & & 60 & 19 & & & & \\
\hline 8 & & & & & & & & \\
\hline 9 & & & & & & & & \\
\hline 10 & 358 & 208 & 150 & 19 & & 192 & 14 & \\
\hline 15 & & & & & 368 & & 25 & 19 \\
\hline 17 & & & & & & & 55 & \\
\hline 20 & 370 & 208 & 198 & 19 & & & 134 & \\
\hline 25 & & & & & & & 166 & \\
\hline 30 & & & & & 370 & 196 & & 19 \\
\hline 60 & & & & 19 & & & 198 & 19 \\
\hline 90 & & & & 19 & & & & 19 \\
\hline
\end{tabular}


was packed with copper pellets of 10-18 mesh size. Results obtained in this work are presented in Table 7 and Figures 1 and 2 .

\section{Table 7}

Conversion of Undiluted Electrolytic Gas

in Copper Tubing (5' Iong, $0.41^{\prime \prime}$ I.D.)

Gas flow rate - $510 \mathrm{cc} / \mathrm{min}$

Space velocity in packed tube $-240 \mathrm{hr}^{-1}$

Salt Bath Temperature

${ }^{\circ} \mathrm{C}$

250

285

300

320

342

368 percent Conversion

\begin{tabular}{cr}
\hline Unpacked Tube & Packed T \\
\hline 4.7 & 61 \\
17.0 & 82 \\
32.0 & 95 \\
53.0 & 100 \\
80.0 & - \\
96.0 &
\end{tabular}

Vanadium Oxide Catalyst

One other preparation was examined as a possible catalyst for the hydrogen-oxygen reaction. This catalyst, prepared in this laboratory, contained $35 \% \quad \mathrm{~V}_{2} \mathrm{O}_{5}$ and $65 \% \mathrm{Al}_{2} \mathrm{O}_{3}$ 。 It was tried out with mixtures of electrolytic gas and steam and also with undiluted electrolytic gas. Using $7.9 \%$ electrolytic gas in stean at $430^{\circ} \mathrm{C}$ and using 40 grams of catalyst, the conversion was $22 \%$ complete. The steam flow rate was 5.5 ilters per minute and the space velocity about $7000 \mathrm{hr}^{-1}$. Thus the performance of this catalyst was rather poor. When used with undiluted electrolytic gas, the percent conversion was better but flashbacks were encountered at apparent catalyst temperatures of $350-360^{\circ} \mathrm{C}$. At a flow rate of $360 \mathrm{cc}$ of undiluted electrolytic gas per minute, the percent conversion at $325^{\circ} \mathrm{C}$ was $62 \%$ 。

The Thermal Reaction Between Hydrogen and Oxygen

When the search for a means of recombining hydrogen and oxygen in the Homogeneous Reactor was first begun, the thermal reaction between hydrogen and oxygen looked attractive because of its simplicity. This reaction has been thoroughly investigated by a number of workers. $3,4,5$ As has been pointed out in the Introduction, the thermal reaction is not synonymous with 


\section{9}

RECOMBINATION OF UNDILUTED ELECTROLYTIC GAS

IN METAL TUBES

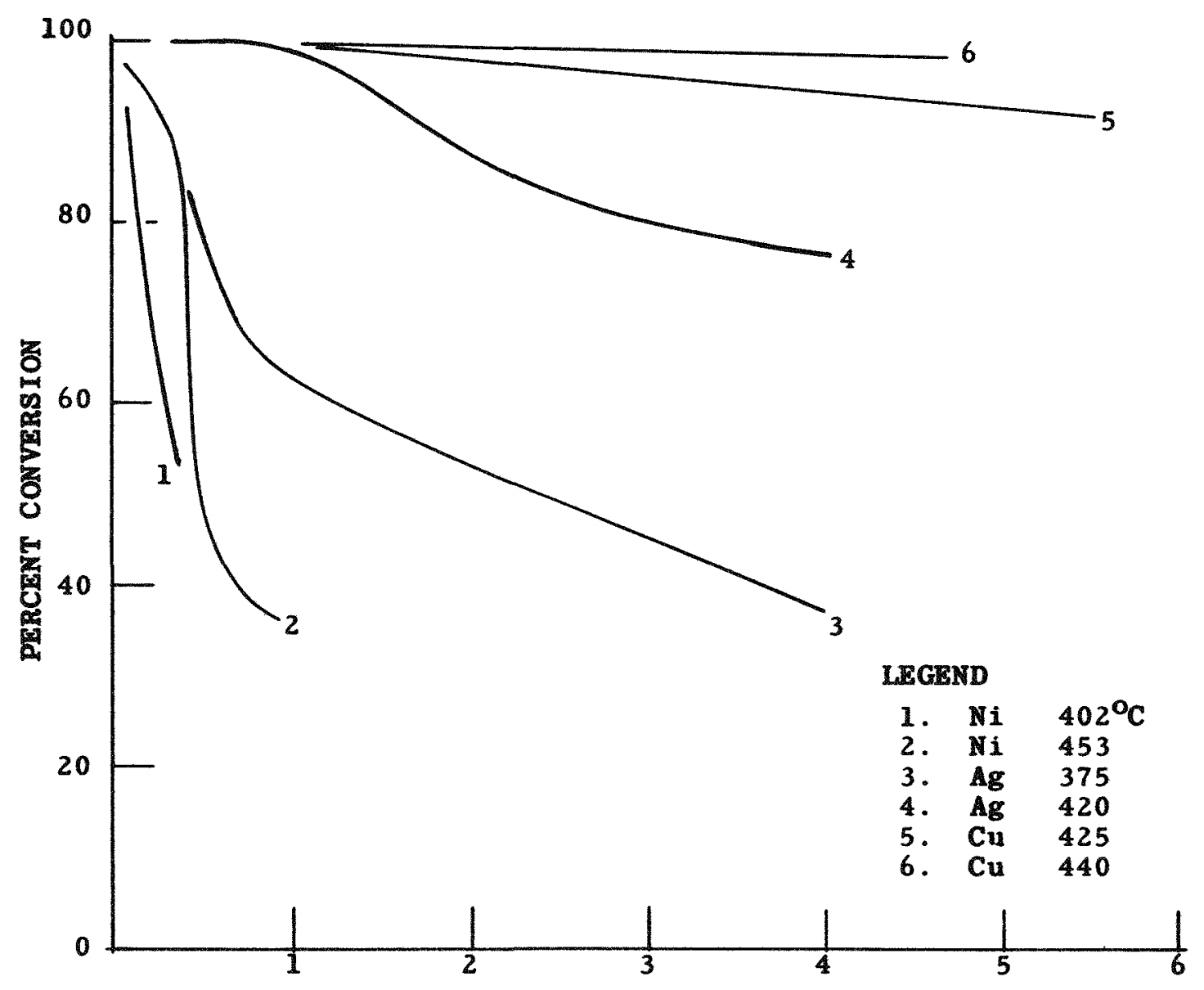

GAS FLOW RATE PER UNIT OF TUBE SURFACE (INTERNAL)

$\mathrm{cc} / \mathrm{min} / \mathrm{cm}^{2}$

Figure 1 


\section{0}

REACTION OF $\mathrm{H}_{2}$ AND $\mathrm{O}_{2}$ ON COPPER

(Five feet of $1 / 2^{\prime \prime} \mathrm{Cu}$ tubing)

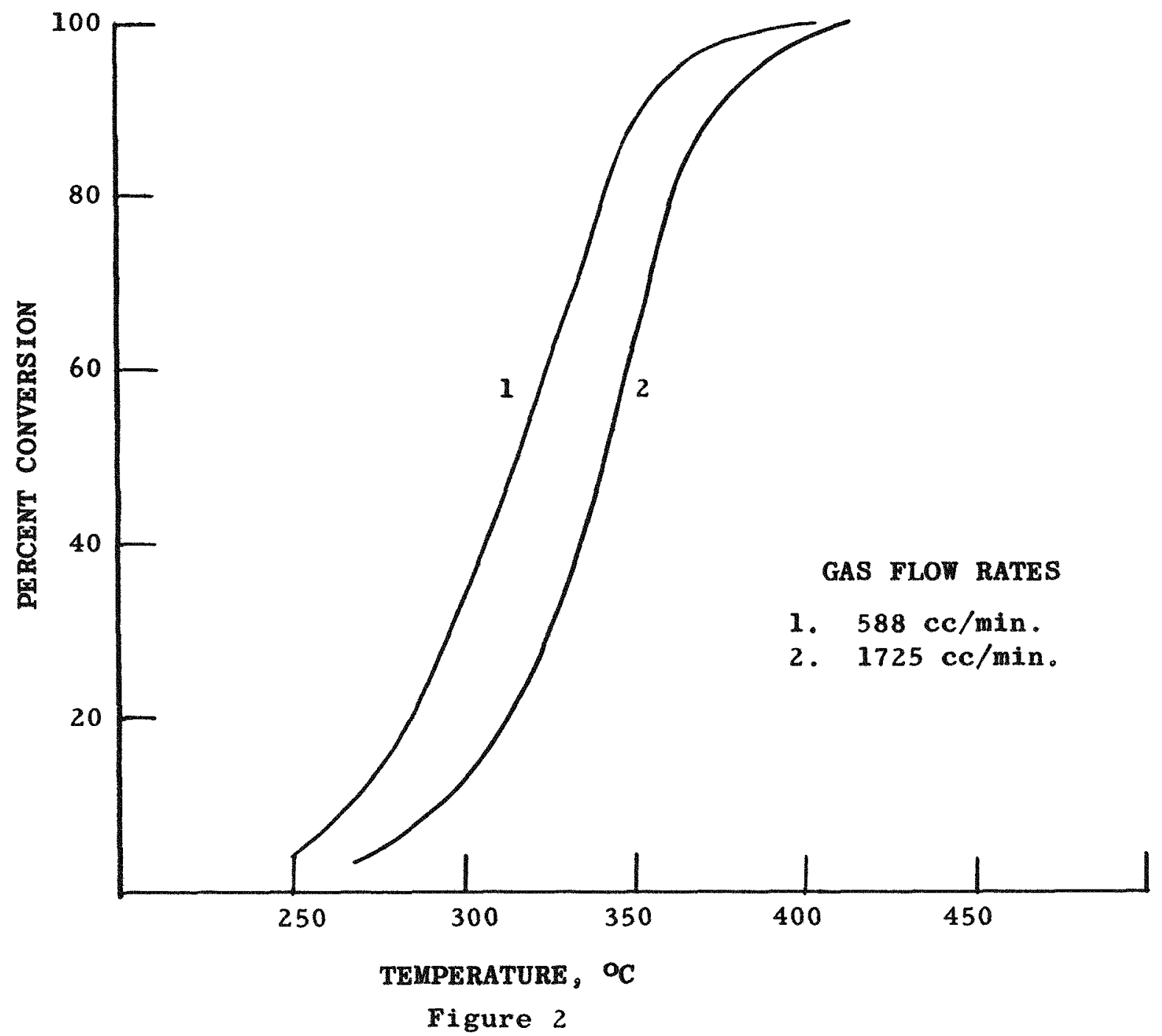


burning, but proceeds by a free radical mechanism. It is only necessary to heat the gases in order to bring about the thermal reaction. Obviously, however, an explosive mixture cannot be heated above the ignition temperature without exploding. Thus the limitation on the thermal reaction is that either the hydrogen and oxygen must be diluted to form a non-explosive mixture, or the temperature must be carefully controlled and maintained below the ignition temperature. For the purpose of this work, it was found that the rate of thermal reaction at temperatures less than the ignition temperature was too slow to be of any practical value. Hence dilute mixtures were studied at higher temperatures.

Preliminary experiments were made to determine the effects of temperature, gas composition, space velocity and types of surfaces upon the efficiency of the reaction. The apparatus was the same as that used for the catalyst studies.

The effect of temperature is shown in Table 8 and in Figure 3. The percent conversion increased rapidiy from 500 to $800^{\circ} \mathrm{C}$. The tests were not extended beyond $800^{\circ} \mathrm{C}$ because of oxidation and corrosion of available metals in this temperature zone.

Comparison of the curves in Figure 4 (or data in Table 9) shows that with dilute gas mixtures the best packing was activated alumina; however, with rich gas the conversion was definitely better without packing.

It is obvious that the efficiency of platinum catalysts is superior to that of the thermal reactor. In fact, comparison of space velocities shows the platinum-on-alumina catalyst to be better by a factor of about 1000 .

\section{SUMMARY}

It has been found that the reaction between hydrogen and oxygen can be effectively carried out by means of a platinum catalyst supported on aluminum oxide. Conversions of better than $99.5 \%$ have been achieved at space velocities as high as $200,000 \mathrm{hr}^{-1}$, although a more conservative figure of 30,000 $\mathrm{hr}^{-1}$ would be recommended. The temperature of operation may be any value from room temperature to $900^{\circ} \mathrm{C}$, provided that the composition of the gas mixture lies below the explosion limit. Steam and helium have been used as diluent gases. 


\section{Table 8}

\section{Thermal Recombination of Hydrogen and Oxygen}

Reactor: Stainless steel tube, 5" diam. X 5" Iong Packing: None

Steam flow: 2.811 ters $/ \mathrm{min} .\left(0^{\circ} \mathrm{C}, 1\right.$ atm.)

Space velocity: $100 \mathrm{hr}^{-1}$

\begin{tabular}{|c|c|c|c|}
\hline $\begin{array}{l}\text { Temp. } \\
\mathrm{O}_{\mathrm{C}} \\
\end{array}$ & $\begin{array}{l}\text { Electrolytic Gas } \\
\text { liters } / \mathrm{min} .\left(0^{\circ} \mathrm{C}, 1 \mathrm{~atm}\right)\end{array}$ & $\begin{array}{l}\text { Percent } \\
\text { Electrolytic } \\
\text { Gas } \\
\end{array}$ & $\begin{array}{l}\text { Percent } \\
\text { Conversion }\end{array}$ \\
\hline 500 & 0.087 & 3.1 & $<5$ \\
\hline 600 & 0.022 & 0.8 & 13 \\
\hline 600 & 0.087 & 3.1 & 20 \\
\hline 700 & 0.022 & 0.8 & 56 \\
\hline 700 & 0.055 & 2.0 & 69 \\
\hline 700 & 0.087 & 3.1 & 78 \\
\hline 800 & 0.022 & 0.8 & 84 \\
\hline 800 & 0.055 & 2.0 & 91 \\
\hline 800 & 0.087 & 3.1 & 93 \\
\hline 800 & 0.110 & 3.9 & 95 \\
\hline
\end{tabular}




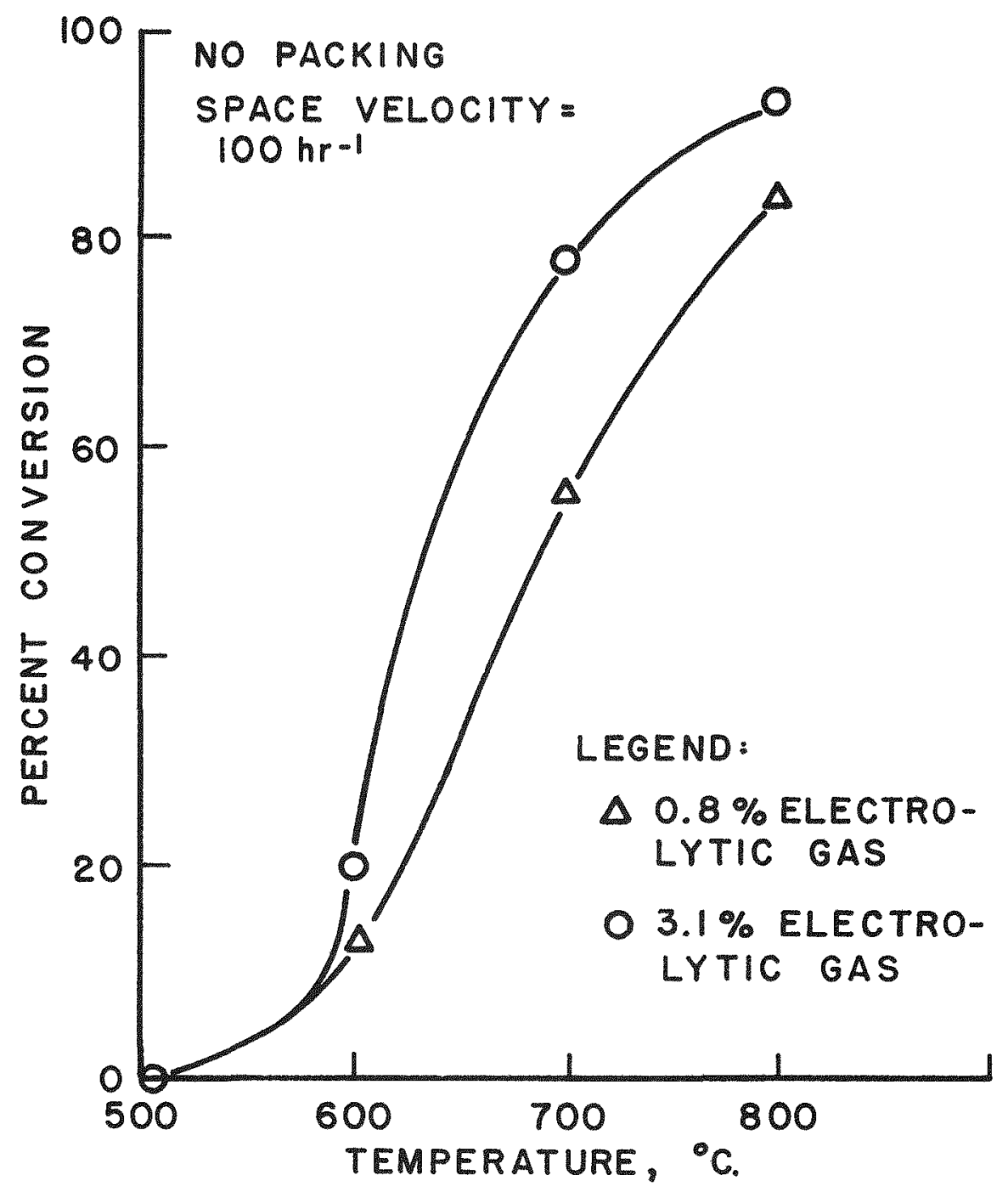

FIGURE 3. THERMAL RECOMBINATION 
Table 9

Thermal Recombination of Hydrogen and Oxygen at $700^{\circ} \mathrm{C}$

Reactor: Stainless steel tube, $5^{\prime \prime}$ diam。 $x 5^{\prime \prime} 1$ ong

Flow Rates

\begin{tabular}{|c|c|c|c|c|c|}
\hline \multirow[b]{2}{*}{$\begin{array}{l}\text { Kind of } \\
\text { Packing }\end{array}$} & \multicolumn{2}{|c|}{1 iters $/ \min \left(0^{\circ} \mathrm{C}, 1 \mathrm{~atm}\right)$} & \multirow{2}{*}{$\begin{array}{c}\text { Percent } \\
\text { Electrolytic } \\
\text { Gas } \\
\end{array}$} & \multirow{2}{*}{$\begin{array}{c}\text { Space } \\
\text { velocjty } \\
\text { hx } x^{-1}\end{array}$} & \multirow[b]{2}{*}{$\begin{array}{l}\text { \% Con- } \\
\text { version }\end{array}$} \\
\hline & Steam & $\begin{array}{l}\text { Electrolytic } \\
\text { Gas } \\
\end{array}$ & & & \\
\hline None & 1.8 & 0.020 & 1.0 & 68 & 74 \\
\hline$n$ & 2.8 & 0.030 & 1.0 & 110 & 58 \\
\hline " & 5.8 & 0.060 & 1.0 & 220 & 50 \\
\hline$n$ & 11.9 & 0.10 & 1.0 & 450 & 32 \\
\hline$n$ & 2.3 & 0.26 & 10.0 & 96 & 91 \\
\hline$" 1$ & 5.7 & 0.63 & 10.0 & 240 & 90 \\
\hline$"$ & 11.5 & 1.3 & 10.0 & 480 & 85 \\
\hline S.Steel & 1.8 & 0.020 & 1.0 & 68 & 65 \\
\hline$"$ & 5.8 & 0.060 & 1.0 & 220 & 37 \\
\hline$"$ & 11.9 & 0.10 & 1.0 & 450 & 21 \\
\hline
\end{tabular}

\section{Activated}

alumina

2.3

0.020

1.0

1. 0

1. 0

0.10

12.2

0.26

10.0

0.62

5.6

1. 3

10.0

10.0

87

220

460

96

230

490

88

68

44

88

79

11.7

1.3

58 


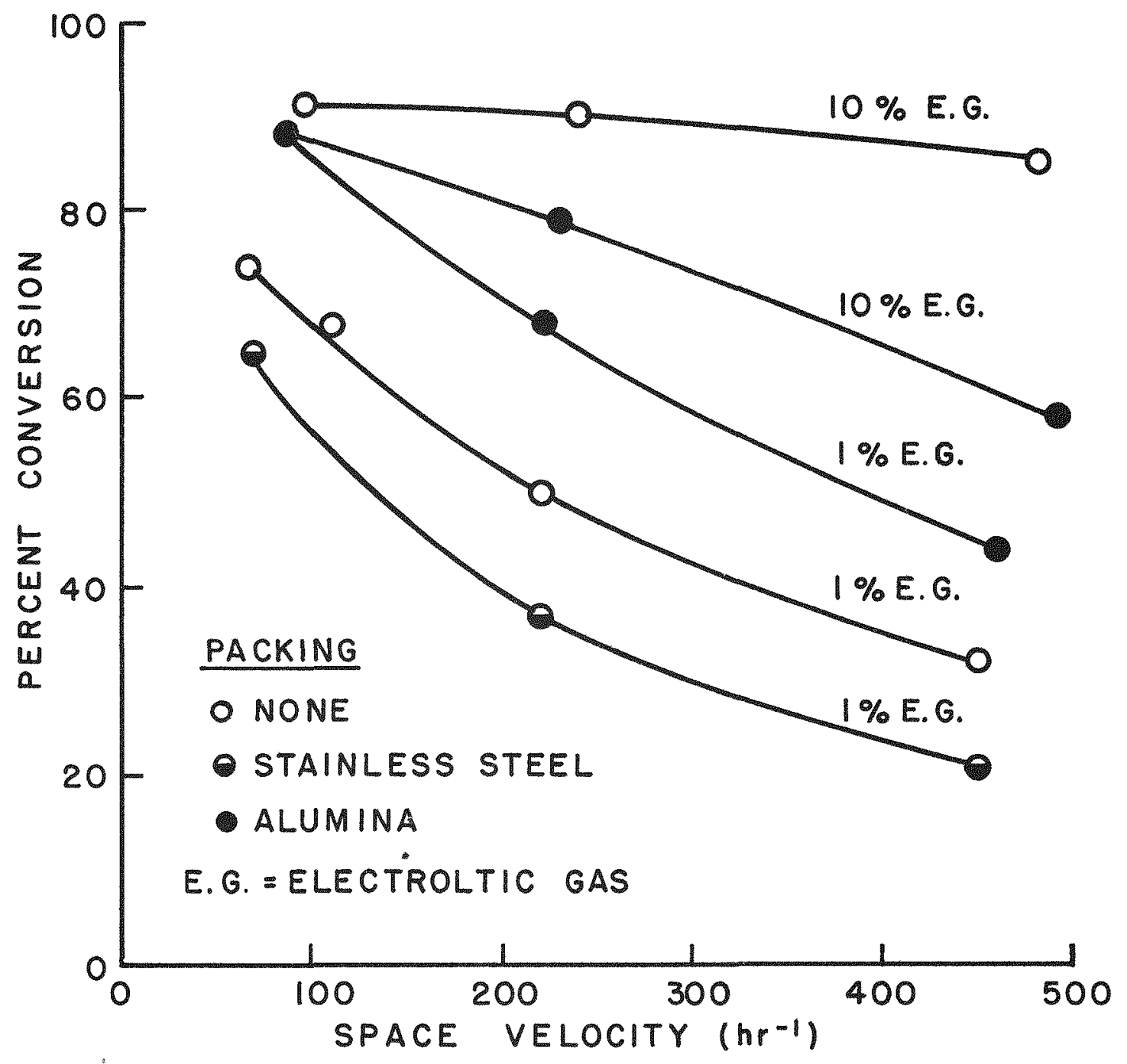

FIGURE 4. THERMAL RECOMBINATION OF HYDROGEN AND OXYGEN AT $700^{\circ} \mathrm{C}$. 
Iodine has been found to poison the catalyst at temperatures of $200-300^{\circ} \mathrm{C}$, but at temperatures above $400^{\circ} \mathrm{C}$ the catalytic activity is essentially unaffected by iodine.

The removal of the heat of reaction from the catalytic unit has been readily accomplished.

The advantages of a twotstage catalytic process have been recognized.

Platinum and palladium have proved to be excellent catalysts for the hydrogen-oxygen reaction. Catalysts which were much less active than platinum but which nonetheless did exhibit catalytic activity for this recombination were copper, silver, nickel, and vanadium pentoxide,

The thermal reaction between hydrogen and oxygen was found to progress at too slow a rate to be of importance.

\section{REFERENCES}

1. McLeod, H. M., Jr., Don Phillips, T。S. Mackey, and W. R. Grimes, "Recombination of Stoichiometric Mixtures of Hydrogen and Oxygen in a Flame Recombiner - Feasibility Report", C\&CCD $-\mathrm{Y}-12, \mathrm{Y}-706$, Jan. 1, 1951 .

2. Kuhn, D. W., F. L. Daley, A. D. Ryon, A. A. Palko and W. R. Grimes, "Explosion Limits in Mixtures of Hydrogen, Oxygen, Steam and Helium", C\&CCD $-\mathrm{Y}-12, \mathrm{Y}-731$, March 1 , 1951.

3. B. Lewis and G. von Elbe, J. Chem. Phys. 10, 366 (1942).

4. 0 . Oldenberg and H. S. Sommers, J. Chem. Phys. 9, 114 (1941).

5. R. B. Holt and O. Oldenberg, J. Chem. Phys. 17, 1091 (1949). 